\title{
The Relation of Parity and Motivation With Post- Placental IUD Selection
}

\author{
Sri Dinengsih", Rosyani \\ Faculty Of Health Science, National University, Indonesia \\ *sridinengsih@civitas.unas.ac.id
}

\begin{abstract}
Intra Uterine Device (IUD) is a contraceptive device that is made of plastic, flexible when it is installed in the uterus. It is an ideal contraception for mothers after childbirth and breastfeeding because it does not suppress the production of breast milk, namely intrauterine contraceptive device (IUD) in addition to 3-month family planning injections, minipil, and condoms (BKKBN, 2016) West Java is not yet known with certainty, but the coverage of family planning services in West Java in 2016 for IUD contraception only reached $11.81 \%$, MOW $2.77 \%$, MOP $0.71 \%$ and implants $6.24 \%$. While non-MKJP contraception, namely condoms, only reached $1.81 \%$, injections 51.94\% and pills $24.72 \%$ (West Java Health Office, 2016).

The research aims to knowing the relationship between parity and motivation with postplacental IUD selection in West Java. This research is a qualitative study using a crosssectional approach with total sampling. Analysis of the results is conducted by calculating the frequency distribution and bivariate analysis with the chi-square test. Result: The result shows that $68.2 \%$ who did not choose a Post Placenta IUD were mothers with primiparous parity while $53.8 \%$ of Post Placenta IUD voters were mothers with multiparous parity, mothers who did not chose a Post-Placental IUD had low motivation of $76.0 \%$ and $65,2 \%$ of mothers with high motivation choose a post Placenta IUD, so there is a relationship between motivation and the selection of a Post-Placental IUD with a $\mathrm{p}$ value of 0.010 . There is no relationship between parity and post-placental IUD selection. There are other variables that are related including post-placental IUD care concerns and knowledge.
\end{abstract}

Keywords : IUD, Post-Placenta, Parity, Motivation. 


\section{STRADA Jurnal Ilmiah Kesehatan}

DOI: $10.30994 /$ sjik.v9i2.339

ISSN: 2252-3847 (print); 2614-350X (online)

Vol.9 No.2 November 2020 Page.435-442

\section{BACKGROUND}

Intra Uterine Device (IUD) is a contraceptive device that is made of plastic; it is flexible when it is installed in the uterus. In 2030, the Sustainable Development Goals (SDG's) indicator is as many as 70 per 100,000 live births (KH), so the efforts to improve family planning services after delivery is the right strategy. Based on RISKEDAS data in 2013 , coverage of deliveries by health workers was quite high at $82.2 \%$.

One of the substances of the Republic of Indonesia's Ministry of Health strategic plan for 2010-2014 is to improve the quality and the reach of family planning services through 23,500 public and private clinics during the 2010-2014 period. Achieving the CPR target is $65 \%$ for the modern method while achieving the unmet need target is as much as 5\% in 2015 (Ministry of Health Republic of Indonesia, 2014)

Post-delivery family planning services strongly support the goal of health development supported by the large number of new KB (Family Planning Program) participants, namely pregnant women and maternity who have had contact with health workers. It is expected that more contact between health workers and pregnant women during examinations and at delivery help will encourage them to use contraception soon after the placenta is born. A mother who has just given birth is usually easier to be invited to use contraception so that the time after giving birth is the right time to invite a mother to use contraception. Therefore, postpartum birth control is expected to reduce the incidence of pregnancy with a distance that is too close and can contribute to avoid complications in pregnancy, childbirth and childbirth which often causes maternal death (Ministry of Health Republic of Indonesia, 2014).

According to the World Health Organization (WHO) contraceptive use has increased in many parts of the world, especially in Asia and Latin America and lowest is in SubSaharan Africa. Globally, users of modern contraception have increased insignificantly from 54\% in 1990 to $57.4 \%$ in 2014. Regionally, the proportion of fertile couples aged 1549 years reported using modern methods of contraception has increased at least the last 6 years. In Africa from $23.6 \%$ to $27.6 \%$, in Asia it has risen from $60.9 \%$ to $61.6 \%$, while Latin America and the Caribbean have risen slightly from $66.7 \%$ to $67.0 \%$. An estimated 225 million women in developing countries want to delay or stop fertility but do not use any contraceptive methods for the following reasons: limited choice of contraceptive methods and experience of side effects (WHO, 2014).

Based on the data of the Indonesian Demographic Health Survey (IDHS) in 2012, contraceptives that were widely used were injections of $31.9 \%$, pills $13.6 \%$, IUD $3.9 \%$, MOW 3.2\%, condoms $1.8 \%$ and MOP 0, 2\%. From these data, it can be seen that the use of MKJP is still relatively low, which means that the achievement target of the program and the reality are still far away. The prevalence of IUD participants decreased over the past 20 years from 13.3\% in 1991 to $4.9 \%$ in 2011 (Statistics Indonesia, 2012)

Various efforts in family planning activities as one of the main activities for the development of a prosperous family have been carried out by the government, the private sector and the community itself, one of them is by promoting the post placenta IUD method, which is an effort to reduce the number of births by reducing the unmet need and missed opportunity in post-mother maternity so that the use of MKJP can reduce the level of drop out and can contribute to reducing the rate of population growth (RI Ministry of Health, 2014).

The impact of population growth that is not controlled will cause problems such as lack of employment opportunities that lead to unemployment and increased crime, forest damage due to arbitrary deforestation that will cause the danger of erosion of landslides 


\section{STRADA Jurnal Ilmiah Kesehatan}

DOI: $10.30994 /$ sjik.v9i2.339

ISSN: 2252-3847 (print); 2614-350X (online)

Vol.9 No.2 November 2020 Page.435-442

and flood hazards, the concentration of population due to urbanization that will lead to order and uncontrolled environmental success and the lack of housing availability that result in a lot of illegal housing which is very disturbing order (Ministry of Health Republic of Indonesia, 2014).

One of the factors that influences the behavior of the use of post-placental IUD is parity. Parity can also affect the behavior of using post-placental IUD. Research conducted by Sugiharti (2009) stated that there is a significant relationship between parity and IUD use. This is not consistent with research conducted by Rochma (2012) with results ( $\mathrm{p}=$ 0.063 ) which means there is no relationship between parity and IUD use. Parity is the number of pregnancies the fetus is born from. High parity allows complications of pregnancy and childbirth which can cause disruption of $\mathrm{O} 2$ transport from mother to fetus which will cause asphyxia which can be assessed from the APGAR Score the first minute after birth (Manuba, 2010).

Motivation can also affect the use of post-placental IUD. Research conducted by Rosa (2012) at the Maripari Community Health Center of 73 respondents with a value ( $\mathrm{p}=$ 0.001) stated that there is a significant relationship between maternal motivation for the use of the IUD. According to Rivai and Sagala (2009), motivation is a series of attitudes and values that influence individuals to achieve specific things in accordance with individual goals.

A preliminary study conducted in the Sukarame Village of the Leles Community Health Center, which had the lowest IUD coverage, was $1.49 \%$ of the 1,134 EFAs. Considering the importance of using the IUD as an effort to reduce the number of births and reduce unmet need and missed opertunity in postpartum mothers so as to reduce the rate of drop out and contribute to reducing the rate of population growth, researchers are interested in taking the title of the relationship of motivation and parity with IUD use behavior post placenta in Sukarame Village Leles Health Center Work Area Garut Regency in 2019.

\section{METHODS}

Research Design

The research process began with a field survey of the low coverage of the PostPlacental IUD. Researchers applied for a research permit from the Leles Public Health Centre Garut, in West Java. Next, the researcher gave a brief explanation of the planned research activities and research objectives to the Respondents and Midwives in charge of $\mathrm{MCH}$ approved by the head of the Leles Public Health Centre, Garut, in West Java with a research permit No; 821/013 / PKM / VII / 2019. The research approach used was a quantitative approach with cross sectional design. The population was all mothers who gave birth in April-June 2019 in Sukarame Village, Leles Public Health Centre, Garut Regency, as many as 48 respondents

\section{Research Variable}

There were 48 Respondents taken the sample. The sampling technique used was total sampling. This study was conducted at Leles Public Health Center in July 2019. The independent variable in this study was Parity and Motivation, while the dependent variable in this study was the Post-Placental IUD selection. 


\section{STRADA Jurnal Ilmiah Kesehatan}

DOI: $10.30994 /$ sjik.v9i2.339

ISSN: 2252-3847 (print); 2614-350X (online)

Vol.9 No.2 November 2020 Page.435-442

Research Instrument

The research instrument used was a closed questionnaire where the respondent only gave a sign $(\sqrt{ })$ on the motivational variable using a Likert scale with alternative answers: strongly disagree rated 1 , disagree rated 2, hesitantly rated 3, agree given 4 and strongly agree given a value of 5. Post-placental IUD IUD variable that is not using a post-placenta IUD then coded 1, and using a post-placenta IUD next it is coded 2. Parity variables based on 2 categories namely primiparous coded 1 and multiparous subsequently coded 2 .

The validity test was conducted by the researchers using 20 respondents at the Lembang Public Health Center in Garut Regency because the characteristics of the village had similarity in the region. The researcher gave 15 question items on the motivational variable that was tested. Based on the results of the validity test using $\mathrm{df}=20-2=18$ in the $r$ table (0.468) with a significant level of $95 \%$ the reliability test obtained cronbach's alpha value of the motivational variable> 0.6 , it can be concluded that the questionnaire has high reliability.

\section{Data Analysis}

Data that had been collected were recapitulated and processed through data processing stages of editing, coding, processing and cleaning. Univariate analysis is done to describe the frequency distribution of each variable, both independent and dependent variables and bivariate analysis with chi-square test using the SPSS program for windows 25 .

\section{RESULT}

Table 1. The Relation of parity with Post-Placental IUD User behavior

\begin{tabular}{|c|c|c|c|c|c|c|c|}
\hline \multirow{3}{*}{ Parity } & \multicolumn{4}{|c|}{ Post-Placental IUD User behavior } & \multicolumn{2}{|c|}{ Total } & \multirow{3}{*}{ P Value } \\
\hline & \multicolumn{2}{|c|}{ Not Use } & \multicolumn{2}{|c|}{ Use } & \multirow{2}{*}{$\mathbf{F}$} & \multirow[b]{2}{*}{$\%$} & \\
\hline & $\mathrm{f}$ & $\%$ & $\mathrm{f}$ & $\%$ & & & \\
\hline Primipara & 15 & 68,2 & 7 & 31,8 & 22 & 100 & \\
\hline \multirow[t]{2}{*}{ Multipara } & 12 & 46,2 & 14 & 53,8 & 26 & 100 & 0,215 \\
\hline & 27 & 56,2 & 21 & 43,8 & 48 & 100 & \\
\hline
\end{tabular}

Based on table 1 above, it shows the relationship between parity and post placenta IUD use behavior. $15(68.2 \%)$ out of 22 respondents with primiparous parity and did not use a post-placental IUD in the Sukarame Village, the Leles Community Health Center, Garut Regency. Then, $14(53.8 \%)$ of the 26 respondents with multiparous parity use a post-placental IUD in the Sukarame Village, Leles Public Health Center Garut Regency.

After conducting a statistical test using Chi Square, the results obtained was $\rho$ value of 0.215 , which means $\rho$-value> 0.05 , so it can be concluded that there is no relationship between parity and post-placental IUD use in the Village of Sukarame, Leles Public Health Center, Garut Regency. 
STRADA Jurnal Ilmiah Kesehatan

DOI: $10.30994 /$ sjik.v9i2.339

ISSN: 2252-3847 (print); 2614-350X (online)

Vol.9 No.2 November 2020 Page.435-442

Table 1. The relation of mother motivation and Post-placental IUD user behavior

\begin{tabular}{|c|c|c|c|c|c|c|c|c|}
\hline \multirow{3}{*}{ Motivation } & \multicolumn{4}{|c|}{ Post-placental IUD } & \multicolumn{2}{|c|}{ Total } & \multirow{3}{*}{$\begin{array}{c}\mathbf{P} \\
\text { Value }\end{array}$} & \multirow{3}{*}{ OR } \\
\hline & \multicolumn{2}{|c|}{ Do not choose } & \multicolumn{2}{|c|}{ Choose } & \multirow{2}{*}{$\mathrm{F}$} & \multirow{2}{*}{$\%$} & & \\
\hline & $\mathrm{F}$ & $\%$ & $\mathrm{~F}$ & $\%$ & & & & \\
\hline Low & 19 & 76,0 & 6 & 24,0 & 25 & 100 & \multirow{3}{*}{0,010} & \multirow{3}{*}{5,938} \\
\hline \multirow[t]{2}{*}{ High } & 8 & 34,8 & 15 & 65,2 & 23 & 100 & & \\
\hline & 27 & 56,2 & 21 & 43,8 & 48 & 100 & & \\
\hline
\end{tabular}

Based on table 2, Above, it shows the relationship between motivation and postplacental IUD use behavior. It is known that as many as 19 (76.0\%) of 25 respondents have low motivation and do not use post-placental IUD in the Sukarame Village Leles Community Health Center Garut District. While as many as $15(65.2 \%)$ of the 23 respondents were highly motivated and used a post-placental IUD in the Sukarame Village, the Leles Public Health Center, Garut Regency.

After a statistical test using Chi Square was conducted, the results obtained was $\rho$ value of 0.010 , which means $\rho$-value $<0.05$ so that it can be concluded that there is a relationship between maternal motivation and post-placental IUD use in the Village of Sukarame, Leles Public Health Center, Garut Regency.

The results of the closeness analysis of the relationship showed an OR (Odd Ratio) value of 5.938 which means that respondents who had low motivation had a 6 times chance of not using post-placental IUD compared to respondents who had high motivation..

\section{DISCUSSION}

Table 1, based on the results of the study, shows the relationship between parity and post-placental IUD use behavior. $15(68.2 \%)$ out of 22 respondents with primiparous parity and did not use a post-placental IUD in the Sukarame Village, the Leles Public Health Center, Garut Regency. There are 14 (53.8\%) of the 26 respondents with multiparaous parity and using a post-placental IUD in the Sukarame Village Leles Publuic Health Center Garut Regency.

According to Hailu (2010), mothers with high parity will have experience compared to mothers who first give birth so that the impact on actions to be taken is in accordance with their objectives.

The results of this study indicated that there is no relationship between parity and the use of a post-placental IUD in the Sukarame Village, Leles Public Health Center, Garut Regency. It us in line with research conducted by Seriawan (2011) with results $(p=0.063)$ which means there is no relationship between parity and IUD use. However, it is different from research conducted by Sugiharti (2009) which states that there is a significant relationship between parity and IUD use.

The assumptions of mothers with high parity in this research area are using a jampersal (labor insurance) program so that information about the conditions that must be done by mothers is one of them using the IUD. 


\section{STRADA Jurnal Ilmiah Kesehatan}

DOI: $10.30994 /$ sjik.v9i2.339

ISSN: 2252-3847 (print); 2614-350X (online)

Vol.9 No.2 November 2020 Page.435-442

Table 2, Based on the results of the study, shows that there is relationship between motivation and post-placental IUD use behavior. It is known that as many as $19(76.0 \%)$ of 25 respondents have low motivation and do not use post-placental IUD in the Sukarame Village Leles Community Health Center Garut District. While as many as 15 (65.2\%) of the 23 respondents were highly motivated and used a post-placental IUD in the Sukarame Village, the Leles Public Health Center, Garut Regency.

After a statistical test using Chi Square was conducted, the results obtained was $\rho$ value of 0.010 , which means $\rho$-value $<0.05$ so it can be concluded that there is a relationship between maternal motivation and post-placental IUD use in the Village of Sukarame, Leles Public Health Center, Garut Regency.

According to Hasibuan (2010), motivation is the thing that causes, distributes, and supports human behavior so that enthusiastically achieve optimal results. According to Samsudin (2009), motivation is a process of influencing or encouraging from outside towards a person or group so that they want to carry out something that has been determined. Another opinion from Rivai and Sagala (2009), motivation is a series of attitudes and values that influence individuals to achieve specific things in accordance with individual goals.

Research conducted by Aldriana (2013) on factors related to the use of intrauterine contraceptive devices (IUD) in the work area of Kabun Puskesmas, Rokan Hulu Regency state that there is a significant relationship between maternal motivation and the use of the IUD with a p-value of 0.002 . Mothers with less motivation, 2,326 times more risk of not using an IUD than mothers with high motivation (95\% CI: OR $=1,447-3,738)$

The assumptions of the researchers is that positive and negative motivation can stimulate someone to behave in achieving optimal results in other words mothers who have positive motivation to spell pregnancy long enough to be able to take care of their children properly will behave to use the IUD post placenta birth

In this study there are some limitations such the study design used is crosssectional which can only show the relationship by observing the independent and dependent variables at the same time, so that it cannot find a causal relationship. It is possible that there are still other variables related to the use of post-placental IUD that are not included in the conceptual framework because of the limitations of the study that only focus on predisposition factor namely parity and motivation.

\section{CONCLUSION}

27 Respondents did not use the post-placental IUD; maternal motivation variable was obtained, 25 respondents having low motivation and parity variable obtained, 26 respondents having high parity. There is a relationship between maternal motivation and the use of post-placental IUD. It needs to improve health education for pregnant women to increase their knowledge to encourage mothers to use post-placental IUD as well as actively participating in health education activities in order to increase their insight so that it creates a high desire for pregnant women to use a post placenta IUD 


\section{STRADA Jurnal Ilmiah Kesehatan}

DOI: $10.30994 /$ sjik.v9i2.339

ISSN: 2252-3847 (print); 2614-350X (online)

Vol.9 No.2 November 2020 Page.435-442

\section{REFERENCES}

Aldriana N., 2013, Gambaran Faktor-faktor yang Mempengaruhi Rendahnya Pemakaian KB AKDR di Puskesmas Rambah Samo I Informasi Tersebut Diharapkan Dapat Menjadi Pertimbangan Untuk Memperbaiki Pelayanan KB AKDR, Jurnal Maternity and Maternal, Vol 1. No 2.

BKKBN, 2014, Buku Panduan Praktis Pelayanan Kontrasepsi Edisi 3. Bina Pustaka, Jakarta.

, 2014, Buku Saku Bagi Petugas Lapangan Program KB Nasional Materi Konseling, BKKBN, Jakarta.

, 2014, Kebijkan dan Strategi Akselerasi Program Kependudukan, KB dan Pembangunan Keluarga TA. 2014, BKKBN, Jakarta.

BPS, 2012, Jakarta Dalam Angka 2012, Badan Pusat Statistik, Jakarta,

Dinkes Garut, 2016, Profil Dinas Kesehatan Garut Tahun 2016, Dinas Kesehatan Kabupaten Garut, Garut.

Dinkes Jabar, 2016, Profil Kesehatan Provinsi Jawa Barat 2016, Dinas Kesehatan Provinsi Jawa Barat, Bandung.

Hasibuan, 2010, Manajemen Sumber Daya Manusia, Edisi Kesembilan, Gunung Agung, Jakarta.

Kemenkes R.I., 2014, Profil Kesehatan Indonesia Tahun 2014, Kementrian Kesehatan Republik Indonesia, Jakarta.

Manuaba, I.B.G., 2010, Ilmu Kebidanan, Penyakit Kandungan dan KB untuk Pendidikan Bidan. Edisi Kedua, EGC, Jakarta.

Pinontoan, et al., 2014, Faktor-Faktor Yang Berhubungan Dengan Penggunaan Alat Kontrasepsi Dalam Rahim Di Puskesmas Tatelu Kabupaten Minahasa Utara, JIDAN, Vol. 2 (2).

Puskesmas Leles, 2018, Laporan Tahunan Puskesmas Leles Tahun 2018, Pusat Kesehatan Masyarakat Leles, Garut.

Rivai, V. \& Sagala, E.J., 2009, Manajemen Sumber Daya Manusia untuk Perusahaan, Rajagrafindo Persada, Jakarta.

Rochma K.M., 2012, Hubungan Pengetahuan Dan Paritas Dengan Pemakaian Alat Kontrasepsi Dalam Rahim (AKDR) Di Wilayah Kerja Puskesmas Gandus Palembang Tahun 2012, Skripsi, Poltekkes Kemenkes Palembang, Palembang. 


\section{STRADA Jurnal Ilmiah Kesehatan}

DOI: $10.30994 /$ sjik.v9i2.339

ISSN: 2252-3847 (print); 2614-350X (online)

Vol.9 No.2 November 2020 Page.435-442

Rosa, 2012, Mirena IUD, Definisi, Cara Kerja, Efek Samping, Kontraindikasi. http;//www.id.shovoong.com// diaksies 29 Mei 2019

Samsudin, 2010, Manajemen Sumber Daya Manusia, Pustaka Setia, Bandung.

Sugiarti, 2009, Faktor Pasangan yang Mempengaruhi Pemilihan Jenis Kontrasepsi pada Pasangan Usia Subur. Universitas Siliwangi Tasikmalaya, Skripsi, Fakultas Ilmu Kesehatan Program Studi Kesehatan Masyarakat. http://journal.unsil.ac.id/jurnalunsil-654- html (diakses pada tanggal 22 Mei 2019)

Sugiyono, 2008, Metode Penelitian Kunatitatif Kualitatif dan R\&D, Alfabeta, Bandung.

Suparyanto, 2011, Konsep Suami dalam Keluarga Berencana, Salemba Medika, Jakarta.

WHO, 2014, World Health Statistics 2014, World Health Organization 